\title{
Interactions between an Arbuscular Mycorrhizal Fungus (Scutellospora heterogama) and the Root-knot Nematode (Meloidogyne incognita) on Sweet Passion Fruit (Passiflora alata)
}

\author{
Érika Cristina Teixeira dos Anjos ${ }^{1}$, Uided Maaze Tiburcio Cavalcante ${ }^{1}$, Danielle Maria \\ Correia Gonçalves ${ }^{1}$, Elvira Maria Regis Pedrosa ${ }^{2}$, Venézio Felipe dos Santos $^{3}$ and Leonor \\ Costa Maia ${ }^{1 *}$ \\ ${ }^{I}$ Departamento de Micologia; Universidade Federal de Pernambuco; Av. Prof. Nelson Chaves, s/n; 50670-420; \\ Recife - PE - Brasil. ${ }^{2}$ Departamento de Tecnologia Rural; Universidade Federal Rural de Pernambuco; Rua Dom \\ Manuel de Medeiros, s/n; Dois Irmãos; 51172-900; Recife - PE - Brasil. ${ }^{3}$ Empresa Pernambucana de Pesquisa \\ Agropecuária; Recife - PE - Brasil
}

\begin{abstract}
The effects of inoculation of sweet passion fruit plants with the arbuscular mycorrhizal (AM) fungus Scutellospora heterogama on the symptoms produced by Meloidogyne incognita race 1 and its reproduction were evaluated in two greenhouse experiments. In the 1st, the M. incognita (5000 eggs/plant) and S. heterogama (200 spores/plant) inoculations were simultaneous; in the $2 n d$, the nematodes were inoculated 120 days after the fungal inoculation. In both the experiments, 220 days after AM fungal inoculation, plant growth was stimulated by the fungus. In disinfested soil, control seedlings (without $\mathrm{S}$. heterogama) were intolerant to parasitism of $\mathrm{M}$. incognita, while the growth of mycorrhized seedlings was not affected. Sporulation of S. heterogama was negatively affected by the nematodes that did not impair the colonization. M. incognita did not affect mycorrhizal seedling growth. The establishment of mycorrhiza prior to the nematode infection contributed for the reduction of symptoms severity and reproduction of $\mathrm{M}$. incognita in disinfested soil.
\end{abstract}

Key words: AMF, biological control, mycorrhizal symbiosis, nematode reproduction, Passifloraceae

\section{INTRODUCTION}

Arbuscular mycorrhizal fungi (AMF) can promote rapid increase in plant growth and contribute to better establishment of seedlings when transplanted to the field. In nursery, inoculation of these fungi can improve the plant growth, reducing the time for seedling production and protecting the plants against soil-borne pathogens, including nematodes (Smith and Read, 1997). Contributing to increase the nutrient uptake and plant vigor, the AMF can act as biological control agents by direct or indirect mechanisms, compensating the damages caused by the nematodes (AzcónAguillar and Barea, 1996). The application of AMF could be an alternative for the nematode management strategy. Furthermore, the nematicides, the most commonly used chemical product to control nematodes, are expensive and toxic, both to the user and to the environment

\footnotetext{
*Author for correspondence: leonorcmaia@yahoo.com.br
} 
(Talavera et al., 2001) and do not have a long lasting effect in the field (Lordello, 1984).

The root-knot nematodes (Meloidogyne spp.) are economically important parasites of fruit plants. They induce the formation of giant cells and root galls that impair water and nutrient uptake to the shoots (Lordello, 1984), reducing the yield and fruit size, and causing the mineral deficiency that decreases plant longevity and a delay in the crop production (Calvet et al., 2001). Arbuscular mycorrhizal fungi and phytoparasitic root-knot nematodes are common soil and root inhabitants. However, they exert opposite effects on plant growth. The interaction between AMF and nematodes results in improvement, reduction or has no effect on disease severity (Hussey and Roncadori, 1982; Maia et al., 2006). This interaction commonly occurs when the seedlings are transplanted to the field and both organisms are capable of colonizing the same roots (Calvet et al., 2001). The effect of the interaction AMF $x$ plant nematodes depends on various factors such as nematode, fungus, and plant species, environmental conditions, time of mycorrhization and period of exposure to the nematode (Talavera et al., 2001). The diversity of results indicates that each nematode-AM fungus-plant combination is unique and generalizations regarding such interactions are not appropriate (Siddiqui and Mahmood, 1995).

Sedentary endoparasitic nematodes (Meloidogyne spp.) cause significant losses in a variety of crops (Society of Nematologists Crop Loss Assessment Committee, 1987). In recent years, a couple of studies of simultaneous inoculation with AMF and nematodes have been conducted to investigate this relationship in different crops, such as tomato (Lycopersicon esculentum Mill.) (Suresh et al., 1985; Talavera et al., 2001); soybean (Glycine max Merril. L.) (Carling et al., 1989); alfalfa (Medicago sativa L.) (Grandison and Cooper, 1986); cotton (Gossypium hirsutum L.) (Smith et al., 1986) and peanut (Arachis hypogaea L.) (Carling et al., 1996). Most of these investigations have been related to biological control of the pathogen in grassland and legumes; a few were performed with fruit plants such as: grapevine (Vitis vinifera L.) (Atilano et al., 1981); peach (Prunus persica L.) (Strobel et al., 1982); banana (Musa sp. L. cv. Grand Naine) (Jaizme-Vega et al., 1997) and peach-almond (Prunus persica Batch $\times$ P. dulcis (Mill.) Webb) (Calvet et al., 2001).
In mycorrhizal plants, the damage caused by the parasitism can be compensated by the increase of plant nutrition, competition for infection site or photosynthates, changes in root morphology, histopathological, biochemical and physiological alterations, and promotion of defense mechanisms to react against the pathogen. It has also been proposed that these factors can act in conjunction (Azcón-Aguillar and Barea, 1996; Dehne, 1982; Hussey and Roncadori, 1982; Ingham, 1988; Maia et al. 2006; Siddiqui and Mahmood, 1995).

The susceptibility of mycorrhizal plants to the nematode parasitism can be characterized by the resistance (suppression or reduction of the nematode reproduction) or tolerance (low or no suppression in plant growth or yield) (Hussey and Roncadori, 1982). For the promotion of resistance or tolerance to this phytoparasite, the selection of AMF is required (Habte et al., 1999). Previous studies have indicated that Scutellospora heterogama (T.H. Nicolson and Gerd.) C. Walker and F.E. Sanders can enhance the growth of sweet passion fruit seedlings (Anjos et al., 2005). Under this condition, seedlings may be able to increase the tolerance to parasitism of root-knot nematodes. The aim of this study was to evaluate the possibility of using $S$. heterogama to protect the passion fruit seedlings (Passiflora alata Curtis) against the root-knot nematode Meloidogyne incognita (Kofoid and White) Chitwood race 1. Thus the effects of the AM fungus-nematode interaction on growth of sweet passion fruit and on pathogen and AMF development was investigated.

\section{MATERIALS AND METHODS}

\section{Substrate}

As substrate a mixture of an argisoil with sand (2:1), characterized by $\mathrm{P}=8 \mathrm{mg} \mathrm{dm}^{-3} ; \mathrm{Al}=0.40$ $\mathrm{cmol}_{\mathrm{c}} \mathrm{dm}^{-3} ; \mathrm{Ca}=0.75 \mathrm{cmol}_{\mathrm{c}} \mathrm{dm}^{-3} ; \mathrm{Mg}=0.40 \mathrm{cmol}_{\mathrm{c}}$ $\mathrm{dm}^{-3} ; \mathrm{K}=0.03 \mathrm{cmol}_{\mathrm{c}} \mathrm{dm}^{-3} ; \mathrm{pH}\left(\mathrm{H}_{2} \mathrm{O}\right)=4.8$ was used, with part being disinfested with methyl bromide before the experiments. Soil humidity was maintained at $60 \%$ of the total pore volume. To minimize the effects of mineral deficiency of the substrate, the plants received nutrient solution without P (Hoagland and Arnon, modified by Jarstfer and Sylvia, 1992), once a week, during the experiments. 


\section{Microorganisms}

Spores of S. heterogama (URM-FMA 05) were multiplied in pot cultures using Panicum miliacium L. as host (Anjos et al., 2005). The nematode $\mathrm{M}$. incognita was propagated on tomato plants (L. esculentum cv. Santa Cruz) (Hussey and Barker, 1973).

\section{Inoculation}

Scutellospora heterogama was inoculated (as soil inoculum, 200 spores plant ${ }^{-1}$ ) into plastic recipients containing $200 \mathrm{~g}$ of soil and one seedling with two leaves. After 15 days, the seedlings were transplanted to plastic bags $(11 \mathrm{~cm}$ diameter $\times 26 \mathrm{~cm}$ height) containing $1700 \mathrm{~g}$ of soil with $12 \mathrm{mg} \mathrm{P} \mathrm{dm}{ }^{-3}$ (added as superphosphate, before planting). A suspension containing 5000 eggs of $M$. incognita race 1 was delivered to each recipient $(2 \mathrm{~cm}$ from the surface) through four holes around the seedling stem. In the experiment I, both the fungus and the nematodes were inoculated after emission of the first two leaves at the time of transplanting. In the experiment II, nematodes were inoculated 120 days after AMF inoculation, when the seedlings reached the height for field transplant $(15 \mathrm{~cm})$ and started the emission of claspers.

\section{Experimental design}

The experiments were carried out in a completely randomized design with factorial arrangement of 2 $\times 2 \times 2$, corresponding to two soil conditions [disinfested (DS) and non disinfested control (DNS)], two treatments of AMF inoculation [with and without $S$. heterogama; (+/- AMF)], two treatments of nematode inoculation (with and without $M$. incognita; +/- NEM) with simultaneous inoculation of AMF and $M$. incognita (Experiment I) and nematode inoculation after the establishment of mycorrhizal symbiosis (Experiment II). Each experiment was carried out with six replicates.

\section{Assessment of variables}

Every 15 days after AMF inoculation, plant height, shoot diameter, number of leaves and the survival rate of the seedlings were registered. After 220 days, the dry weight of the shoot and the fresh weight of the roots, root colonization and AMF spores density were accessed. Root gall symptoms, $M$. incognita egg masses, and root eggs (signals) were also evaluated. AMF colonization was estimated (Giovannetti and Mosse, 1980) through observations of $1 \mathrm{~cm}$ stained (Kormanic and McGraw, 1984) root fragments. AMF spores were extracted from the soil by wet sieving (Gerdemann and Nicolson, 1963) and sucrose centrifugation (Jenkins, 1964). Root galls and egg masses were counted and the results were expressed per gram of roots and per root systems. Eggs were extracted from galled root systems with sodium hypoclorite ( $\mathrm{NaOCl} 1 \%)$ (Hussey and Barker, 1973) and counted in a Peter's $1 \mathrm{~mL}$ slide. The increment promoted by mycorrhizal inoculation was estimated by the formula: $\mathrm{I}(\%)=[\mathrm{Tr}-\mathrm{T} / \mathrm{T}] \times 100(\mathrm{I}=$ increment, $\mathrm{Tr}=$ specific treatment and $\mathrm{T}=$ control).

\section{Statistical analysis}

The data were submitted to the analysis of variance (ANOVA) and single correlation was obtained. The treatment means were compared by the Tukey test at 0.05 probability. The data of nematode and AMF growth were $\log _{10}(x+1)$ transformed and the number of leaves was used as the $\arcsin (\sqrt{ } x+0.5)$. The degrees of Miller (1994) were considered for the magnitude of the correlation.

\section{RESULTS}

\section{Experiment 1}

Significant interactions between AMF $\times$ nematode on plant height and stem diameter were found 90 days after inoculation (Table 1). The inoculation with $S$. heterogama, when nematodes were absent, promoted an increment of $112.2 \%$ in plant height and $56.3 \%$ in stem diameter after 90 days, in comparison with the uninoculated seedlings. Until the 75th day the mycorrhizal seedlings were bigger than those of the control treatment, independently of the presence of nematodes; after this period, differences between the mycorrhizal and nonmycorrhizal seedlings occurred only in the absence of nematodes. In all the periods, $M$. incognita inhibited the seedlings growth, both in the mycorrhizal and non-mycorrhizal treatments (Table 1).

Interactions between $S$. heterogama $\times M$. incognita were observed through the number of spores of the fungus. Nematode infestation inhibited the sporulation of $S$. heterogama that produced 15 times more spores when the pathogen was absent, independently of soil disinfestation (Table 2). 
Table 1 - Plant height $(\mathrm{cm})$ and stem diameter $(\mathrm{mm})$ of passion fruit seedlings 60, 75 and 90 days after joint inoculation of Scutellospora heterogama (AMF) and Meloidogyne incognita (NEM)

\begin{tabular}{|c|c|c|c|c|}
\hline \multirow{2}{*}{ Inoculation } & \multicolumn{2}{|c|}{ Plant height } & \multicolumn{2}{|c|}{ Stem diameter } \\
\hline & + NEM & - NEM & + NEM & - NEM \\
\hline & \multicolumn{4}{|c|}{60 days $(*)$} \\
\hline$+\mathrm{AMF}$ & $4.47 \mathrm{aB}$ & $5.65 \mathrm{aA}$ & $1.79 \mathrm{aB}$ & $2.23 \mathrm{aA}$ \\
\hline - AMF & $3.60 \mathrm{bA}$ & $3.85 \mathrm{bA}$ & $1.80 \mathrm{aA}$ & $1.85 \mathrm{bA}$ \\
\hline \multirow[t]{2}{*}{$\mathrm{CV}(\%)$} & \multicolumn{2}{|c|}{16.92} & \multicolumn{2}{|c|}{9.46} \\
\hline & \multicolumn{4}{|c|}{75 days $(* *)$} \\
\hline$+\mathrm{AMF}$ & $5.10 \mathrm{aB}$ & $8.50 \mathrm{aA}$ & $2.09 \mathrm{aB}$ & $3.11 \mathrm{aA}$ \\
\hline - AMF & $3.89 \mathrm{bA}$ & $4.48 \mathrm{bA}$ & $1.96 \mathrm{aA}$ & $2.11 \mathrm{bA}$ \\
\hline \multirow[t]{2}{*}{$\mathrm{CV}(\%)$} & \multicolumn{2}{|c|}{17.60} & \multicolumn{2}{|c|}{9.00} \\
\hline & \multicolumn{4}{|c|}{90 days $(* *)$} \\
\hline$+\mathrm{AMF}$ & $5.30 \mathrm{aB}$ & $11.46 \mathrm{aA}$ & $2.05 \mathrm{aB}$ & $3.36 \mathrm{aA}$ \\
\hline - AMF & $4.12 \mathrm{aA}$ & $5.40 \mathrm{bA}$ & $1.94 \mathrm{aA}$ & $2.15 \mathrm{bA}$ \\
\hline $\mathrm{CV}(\%)$ & \multicolumn{2}{|c|}{22.41} & \multicolumn{2}{|c|}{13.14} \\
\hline
\end{tabular}

Data (means of 6 pot replicates) followed by the same letters in a column (a, b) and in a line (A, B) for a given parameter and sampling date do not differ significantly $(\mathrm{P} \leq 0.05)$ by the Tukey test after analyses of variances. **(P $\leq 0.01) ; *(\mathrm{P} \leq 0.05) ;(+)$ present; (-) absent. (CV) coefficient of variation.

Table 2 - Spore numbers of S. heterogama (per $50 \mathrm{~g}$ soil) in the rhizosphere of sweet passion fruit seedlings 220 days after joint inoculation of Scutellospora heterogama and Meloidogyne incognita, independently of soil disinfestations.

\begin{tabular}{lcc}
\hline & \multicolumn{2}{c}{ Number of spores/50 g soil (**) } \\
\cline { 2 - 3 } Inoculation & $+\mathbf{N E M}$ & - NEM \\
\hline+ AMF & $74.00 \mathrm{aB}$ & $1180.33 \mathrm{aA}$ \\
- AMF & $17.83 \mathrm{aA}$ & $20.16 \mathrm{bA}$ \\
\hline CV $(\%)$ & & 32.55 \\
\hline
\end{tabular}

Data (means of 6 pot replicates) followed by the same letters in a column (a, b) and in a line (A, B) do not differ significantly $(\mathrm{P} \leq 0.05)$ using Tukey test after analyses of variances. **(P $\leq 0.01)$; (+) present; (-) absent; (CV) coefficient of variation.

\section{Experiment II}

Seedlings associated with $S$. heterogama presented a significant difference in fresh root biomass 220 days after inoculation, with interactions between the fungus $x$ soil disinfestation and nematode $\times$ soil disinfestation. In all the treatments, fresh root biomass was lower in disinfected soil than in the control soil. Inoculation with $S$. heterogama promoted the biomass increment of $1537 \%$ in disinfested soil in relation to the treatment without AMF, while no differences occurred in control soils. However, when nematodes were inoculated in the control soil, the seedlings presented lower fresh root biomass (Table 3). 
Table 3 - Fresh root biomass of sweet passion fruit seedlings 220 days after inoculation of Scutellospora heterogama (AMF) and Meloidogyne incognita (NEM) in disinfested and non-disinfested control soil.

\begin{tabular}{lcc}
\hline \multirow{2}{*}{ Inoculation } & \multicolumn{2}{c}{ Fresh root biomass $(\mathbf{g})(* *)$} \\
\cline { 2 - 3 } & Disinfested soil & Non-disinfested \\
\hline - AMF & $10.64 \mathrm{aB}$ & $13.98 \mathrm{aA}$ \\
AMF & $0.65 \mathrm{bB}$ & $14.24 \mathrm{aA}$ \\
\hline$+\mathrm{NEM}$ & & $12.45 \mathrm{bA}$ \\
- NEM & $6.84 \mathrm{aB}$ & $15.78 \mathrm{aA}$ \\
\hline
\end{tabular}

$\mathrm{CV}(\%)$

40,6

Data (means of 6 pot replicates) followed by the same letters in a column (a, b) and in a line (A, B) do not differ significantly $(\mathrm{P} \leq 0.05)$ by the Tukey test after analyses of variance. **(P $\leq 0.01) ;(+)$ present; (-) absent; (CV) coefficient of variation.

There were interactions between S. heterogama $\times$ M. incognita $\times$ soil condition, regarding the number of root-knot galls, egg and egg masses. In the treatments inoculated with $S$. heterogama, reductions of $72 \%$ in the number of galls per $g$ of roots and $87.7 \%$ in egg masses per $g$ of roots were observed in disinfested soil. In the control soil, the number of eggs and galls per root system were reduced 44 and $26.5 \%$, respectively. However, in this soil treatment, gall number, egg number and egg masses per root system increased in the mycorrhizal seedlings. Pathogen development differed between the disinfested and control soils without $S$. heterogama (Table 4).

Table 4 - Effects of inoculation of Scutellospora heterogama (AMF) and soil disinfestation on plant disease symptoms and nematode reproduction in roots of sweet passion fruit seedlings, infested with Meloidogyne incognita, 220 days after inoculation.

\begin{tabular}{|c|c|c|}
\hline \multirow{2}{*}{ Inoculation } & Disinfested soil & Non-disinfested soil \\
\hline & \multicolumn{2}{|c|}{ Gall/root systems $(* *)$} \\
\hline$+\mathrm{AMF}$ & $244,00 \mathrm{aA}$ & $270,33 \mathrm{bA}$ \\
\hline - AMF & $56,25 \mathrm{bB}$ & $367,80 \mathrm{aA}$ \\
\hline \multirow[t]{2}{*}{$\mathrm{CV}(\%)$} & \multicolumn{2}{|c|}{9,56} \\
\hline & \multicolumn{2}{|c|}{ Gall/g root $(*)$} \\
\hline$+\mathrm{AMF}$ & $21,06 \mathrm{bA}$ & $21,21 \mathrm{aA}$ \\
\hline - AMF & $75,27 \mathrm{aA}$ & $30,14 \mathrm{aB}$ \\
\hline \multirow{2}{*}{$\mathrm{CV}(\%)$} & \multicolumn{2}{|c|}{16,69} \\
\hline & \multicolumn{2}{|c|}{ Egg masses/root systems (*) } \\
\hline$+\mathrm{AMF}$ & $86,00 \mathrm{aA}$ & $107,33 \mathrm{aA}$ \\
\hline - AMF & $42,50 \mathrm{bB}$ & $137,20 \mathrm{aA}$ \\
\hline \multirow[t]{2}{*}{$\mathrm{CV}(\%)$} & \multicolumn{2}{|c|}{16,45} \\
\hline & \multicolumn{2}{|c|}{ Egg masses/g root $(* *)$} \\
\hline$+\mathrm{AMF}$ & $7,40 \mathrm{bA}$ & $8,63 \mathrm{aA}$ \\
\hline - AMF & $60,17 \mathrm{aA}$ & $11,81 \mathrm{aB}$ \\
\hline \multirow[t]{2}{*}{$\mathrm{CV}(\%)$} & \multicolumn{2}{|c|}{34,51} \\
\hline & \multicolumn{2}{|c|}{ Egg number/root systems $(* *)$} \\
\hline$+\mathrm{AMF}$ & $6655,00 \mathrm{aA}$ & $8308,00 \mathrm{bA}$ \\
\hline - AMF & $64,50 \mathrm{bB}$ & $14857,00 \mathrm{aA}$ \\
\hline $\mathrm{CV}(\%)$ & \multicolumn{2}{|c|}{19,54} \\
\hline
\end{tabular}


The fungus development and nematode reproduction were positively correlated with the production of galls and egg masses on roots of sweet passion fruit. Conversely, there was negative correlation between the number of galls per $g$ of root (NGR) and mycorrhizal colonization (RC), and between the number of egg masses per $g$ of root $(E M R) \times$ root colonization as well as number of AMF spores (Table 5).

Table 5 - Correlation coefficient ( $r$ ) of parameters related to the nematode Meloidogyne incognita and AM fungus Scutellospora heterogama in roots and rhizosphere of sweet passion fruit 220 days after inoculation with the nematodes.

\begin{tabular}{lcc}
\hline Parameter $^{\text {a }}$ & Coefficient & Degree \\
\hline $\mathrm{NG} \times \mathrm{RC}$ & $0.8065 * *$ & Very high \\
$\mathrm{NG} \times \mathrm{NS}$ & $0.6865 * *$ & Substantial \\
$\mathrm{NGR} \times \mathrm{RC}$ & $-0.4907 *$ & Moderate \\
$\mathrm{NEM} \times \mathrm{RC}$ & $0.7261 * *$ & Very high \\
$\mathrm{NEM} \times \mathrm{NS}$ & $0.6984 * *$ & Substantial \\
$\mathrm{EMR} \times \mathrm{RC}$ & $-0.7630 * *$ & Very high \\
$\mathrm{EMR} \times \mathrm{NS}$ & $-0.6379 * *$ & Substantial \\
\hline
\end{tabular}

$\mathrm{P} \leq 0.01$ (**) e $\mathrm{P} \leq 0.05$ (*). ${ }^{\mathrm{a}} \mathrm{NG}=$ Number of $M$. incognita galls; RC = Root colonization by $S$. heterogama; NS = Number of spores of $S$. heterogama/50 g soil; NGR = Number of galls/g root; NEM = Number of egg masses; EMR = Number of egg masses/g root. The degrees of Miller (1994) were considered for the magnitude of the correlation.

\section{DISCUSSION}

The seedlings of sweet passion fruit were positively responsive to association with $S$. heterogama, showing growth increment. These results reinforced the previous studies with the same combination of host and AMF (Anjos et al., 2005), and also with yellow passion fruit (Cavalcante et al., 2002). The growth increase of the seedlings (24\% in plant height) was suppressed by $M$. incognita as also observed by Strobel et al. (1982) in peach, with reduction of 50\% plant growth. In peanut, Meloidogyne arenaria (Neil) Chitwood suppressed both root and shoot growth (Carling et al., 1996). The decrease in plant shoot development associated with nematode parasitism usually is related to the interruption of water and nutrients translocation by the giant cells (Cofcewicz et al., 2001).

In spite of some results (Pandey et al., 1999; Pinochet et al., 1996) showing tolerance of mycorrhizal plants to nematode infection, in this study the seedlings were intolerant to parasitism of $M$. incognita, even in the presence of $S$. heterogama, when both (AM fungus and nematode) were simultaneously inoculated. The high severity of symptoms in control soils could be a result of secondary infections by other pathogenic microorganisms (Agrios, 1988). Likewise, tomato plants infested by $M$. incognita at the time of transplanting were not protected by
Glomus mosseae (T.H. Nicolson and Gerd.) Gerd. and Trappe (Talavera et al., 2001). The growth of mycorrhizal coffee plants (Coffea arabica L.) was also reduced when Pratylenchus coffeae Zimmermann was inoculated before the establishment of the symbiosis (Vaast et al., 1998). The growth of sweet passion fruit seedlings was not affected by the inoculation of the root-knot nematode after mycorrhizal establishment. Grandison and Cooper (1986) observed that previously established mycorrhizal colonization increased the resistance of a susceptible cultivar of alfalfa to Meloidogyne hapla Chitwood. The inoculation of Glomus fasciculatum (Thaxt.) Gerd. and Trappe seven days prior to inoculation with Radopholus similis (Cobb) Thorne inhibited the reproduction of the phytoparasite (Umesh et al., 1988). The nematodes have an advantage in the competition for root space and further reproduction as root colonization by AMF takes from 2 to 4 weeks, while the penetration of the nematode in the roots occur in a few hours (Talavera et al., 2001). Sikora and Sitaramaiah (1980) suggested that in order to obtain a better response of the development of seedlings, the inoculation with AMF should be done at least four weeks before the transplantation to a field infected with nematodes. Inoculation of AMF before transplantion of the seedlings to the field is an important requirement for protection against nematodes as it gives time for establishment of the 
association before the contact with the parasite (Calvet et al., 2001).

The natural population of AM fungi was not able to multiply as efficiently as $S$. heterogama, even when nematodes were absent, indicating that not always the native AMF are the best option for plant inoculation. The nematodes negatively affected the sporulation, but did not impair the root colonization of seedlings by $S$. heterogama when the inoculation (AMF and nematode) was simultaneous. When the mycorrhiza was established prior to nematode inoculation, both sporulation and colonization by $S$. heterogama were not affected by the pathogen. Hussey and Roncadori (1982) showed variable effects on nematodes in the fungal sporulation, the latter sometimes being inhibited. However, adverse effects rarely occurred in relation to root colonization. In Allium cepa L., root colonization was not affected by $M$. hapla, while spores density was significantly lower in the presence of the pathogen (Kotcon et al., 1985). Meloidogyne arenaria decreased the sporulation and root colonization by AMF and it was suggested that the effect occurred by direct action in the plants, with anatomical and physiological changes interfering in water and nutrients translocation to the roots and shoots (Atilano et al., 1981). Kellam and Schenck (1980) observed that arbuscles and vesicles closer to gall tissues were decomposed or atypical, showing that this environment was unfavorable for the fungi.

The effect of the mycorrhizal fungi against the nematodes (number of galls, eggs and egg masses) was clearly observed. This difference in the response, considering gram of root $\times$ root systems, probably reflected the biomass of mycorrhizal and control seedlings. The roots of mycorrhizal seedlings were denser than those uninoculated, cultivated in disinfested soil, providing a larger surface for penetration sites than the control treatment that allowed increase of the final population of nematodes. In control soil, the number of galls and eggs per root system was reduced although fresh root biomass of seedlings did not differ between the treatments. There was, probably, a synergistic effect among the soil microorganisms, as also observed in the studies with plant growth promoting bacteria, Pseudomonas fluorescens Migula (Siddiqui and Mahmood, 1998), and with the nematophagous fungus Paecilomyces lilacinus (Thom) Samson (Al-Raddad, 1995). When associated with AM fungi, the effects of these organisms were more pronounced than in the absence of AMF.

Jaizme-Vega et al. (1997) compared the number of galls and eggs per total root biomass and per $g$ of root of banana plants and found that the latter would express the levels of nematode reproduction and infection with higher confidence. However, in this study, the positive effect of the interaction with $S$. heterogama was observed even in the number of galls and eggs per total root biomass.

It was shown that the intensity of colonization by AMF might be a determining factor on the response of mycorrhized plants to nematode parasitism (Grandison and Cooper, 1986; Smith et al., 1986). Meloidogyne hapla was absent in cortical tissues with more than $10 \%$ mycorrhizal colonization (Grandison and Cooper, 1986). M. incognita was significantly inhibited when $50 \%$ of cotton roots were colonized by $G$. intraradices, but was not affected when colonization was lower than $50 \%$ (Smith et al., 1986). The $40 \%$ colonization produced by $S$. heterogama in the roots of sweet passion fruit seedlings apparently was enough to negatively affect the development of $M$. incognita on the host.

Borowicz (2001) mentioned various studies where a decrease in reproduction of sedentary nematodes occurred in the presence of AMF, suggesting that this reduction was due to physiological changes produced by the fungus in the root system. This could modify the attractiveness of the roots or induce a physical or chemical barrier, impairing nematode penetration. The reduction of the number of eggs in the roots of sweet passion fruit seedlings when $S$. heterogama was established indicated that the fungus enhanced the resistance to parasitism (Hussey and Roncadori, 1982). In soybean, resistance to $M$. incognita was promoted by Glomus etunicatum W.N. Becker and Gerd. (Carling et al., 1989). The plant resistance is governed by external or internal factors that can reduce the opportunity of the pathogen to infect or diminish the infection level (Agrios, 1988).

The reduction in number of galls, egg masses and eggs observed on roots of the seedlings could be due to competition between the pathogen and the symbiont for infection sites, but other factors such as increase of lignin and phenols (Umesh et al., 1988) or nematicide substances, such as phenylalanine and serine (Suresh et al., 1985) can be involved. Kellam and Schenck (1980) registered lower quantity of galls in mycorrhizal soybean plants than in non- mycorrhizal. This could be a 
result of the reduction in the ability of the nematode to penetrate in the root or of the presence of the AMF affecting the formation of giant cells and further development of the nematodes.

The increase in vigor also helped the mycorrhizal plants to endure the parasitism of the nematode. The nutritional benefit promoted by G. etunicatum on tomato plants contributed for increasing the resistance to M. javanica (Cofcewicz et al., 2001). The establishment of mycorrhizal association with $S$. heterogama prior to nematode contact was beneficial for sweet passion fruit plants conferring conditions for improved plant growth in the presence of the pathogen.

\section{RESUMO}

O efeito da inoculação com Scutellospora heterogama (200 esporos/planta) em relação aos sintomas e reprodução de Meloidogyne incognita raça 1 (5000 ovos/planta) foi avaliado em plantas de maracujazeiro doce em dois experimentos em casa de vegetação. No primeiro experimento, inoculações com nematóide e FMA foram simultâneas; no segundo, nematóides foram inoculados 120 dias após o estabelecimento da simbiose micorrízica. Após o $220^{\circ}$ dia da inoculação do FMA o fungo estimulou o crescimento da planta nos dois experimentos. No solo desinfestado as mudas não inoculadas com $S$. heterogama mostraram intolerância ao parasitismo de $M$. incognita. A esporulação de $S$. heterogama foi negativamente afetada pela presença do nematóide. $M$. incognita não afetou o crescimento das mudas micorrizadas ou o desenvolvimento do FMA. O estabelecimento da micorriza antes do nematóide contribui para a redução da severidade dos sintomas e reprodução de $M$. incognita em solo desinfestado.

\section{REFERENCES}

Agrios, G.N. (1988), Plant Pathology. Academic Press, San Diego.

Al-Raddad, A.M. (1995), Interaction of Glomus mosseae and Paecilomyces lilacinus on Meloidogyne javanica of tomato. Mycorrhiza, 5, 233-236.

Anjos, E.C.T., Cavalcante, U.M.T., Santos, V.F.S. and Maia, L.C. (2005), Produção de mudas de maracujazeiro-doce micorrizadas em solo desinfestado e adubado com fósforo. Pesquisa Agropecuária Brasileira, 40, 345-351.

Atilano, R.A., Menge, J.A. and Van Gundy, S.D.V. (1981), Interaction between Meloidogyne arenaria and Glomus fasciculatum in grape. Journal of Nematology, 13, 52-57.

Azcón-Aguillar, C. and Barea, J. M. (1996), Arbuscular mycorrhizas and biological control of soil-borne plant pathogens-an overview of the mechanisms involved. Mycorrhiza, 6, 457-464.

Borowicz, V.A. (2001), Do arbuscular mycorrhizal fungi alter plant-pathogens relations? Ecology, 82, 3057-3068.

Calvet, C., Pinochet, J., Hernández-Dorrego, A., Estaún, V. and Camprubi, A. (2001), Field microplot performance of the peach-almond hybrid GF-677 after inoculation with arbuscular mycorrhizal fungi in a replant soil infested root-knot nematodes. Mycorrhiza, 10, 295-300.

Carling, D.E., Roncadori, R.W. and Hussey, R.S. (1989), Interactions of vesicular-arbuscular mycorrhizal fungi, root-knot nematode and phosphorus fertilization on soybean. Plant Disease, 73, 730-733.

Carling, D.E., Roncadori, R.W. and Hussey, R.S. (1996), Interactions of arbuscular mycorrhizae, Meloidogyne arenaria, and phosphorus fertilization on peanut. Mycorrhiza, 6, 9-13.

Cavalcante, U.M.T., Maia, L.C., Costa, C.M.C., Cavalcante, A.T. and Santos, V.F. (2002), Efeito de fungos micorrízicos arbusculares, da adubação fosfatada e da esterilização do solo no crescimento de mudas de maracujazeiro amarelo. Revista Brasileira de Ciência do Solo, 26, 1099-1106.

Cofcewicz, E.T., Medeiros, C.A.B. and Carneiro, R.M.D.G. and Pierobom, C.R. (2001), Interação dos fungos micorrízicos arbusculares Glomus etunicatum e Gigaspora margarita e o nematóide das galhas Meloidogyne javanica em tomateiro. Fitopatologia Brasileira, 26, 65-70.

Dehne, H.W. (1982), Interaction between vesiculararbuscular mycorrhizal fungi and plant pathogens. Phytopathology, 72, 1115-1119.

Gerdemann, J.W. and Nicolson, T.H. (1963), Spores of mycorrhizal Endogone extracted from soil by wet sieving and decanting. Transactions of the British Mycological Society, 46, 235-244.

Giovannetti, M. and Mosse, B. (1980), An evaluation of techniques for measuring vesicular arbuscular mycorrhizal infection in roots. New Phytologist, 84, 489-500.

Grandison, G.S. and Cooper, K.M. (1986), Interaction of vesicular-arbuscular mycorrhizae and cultivars of alfalfa susceptible and resistant to Meloidogyne hapla. Journal of Nematology, 18, 141-149. 
Habte, M., Zhang, Y.C. and Schmitt, D.P. (1999), Effectiveness of Glomus species in protecting white clover against nematode damage. Canadian Journal of Botany, 77, 135-139.

Hussey, R.S. and Barker, K.R. (1973), A comparison of methods of collecting inocula of Meloidogyne spp. including a new technique. Plant Disease Reporter, 57, 1025-1028.

Hussey, R.S. and Roncadori, R.W. (1982), Vesiculararbuscular mycorrhizae may limit nematode activity and improve plant growth. Plant Disease, 66, 9-14.

Ingham, R.E. (1988), Interactions between nematodes and vesicular-arbuscular mycorrhizae. Agriculture Ecosystems and Environment, 24, 169-182.

Jaizme-Vega, M.C., Tenoury, P., Pinochet, J. and Jaumot, M. (1997), Interactions between the rootknot nematode Meloidogyne incognita and Glomus mosseae in banana. Plant and Soil, 196, 27-35.

Jarstfer, A.G. and Sylvia, D.M. (1992), Inoculum production and inoculation strategies for vesiculararbuscular mycorrhizal fungi. In Soil Microbial Tecnologies, Applications in Agriculture, Forestry and Environmental Management, ed. B. Metting. Marcel Dekker, New York, pp. 349-377

Jenkins, W.R.A. (1964), A rapid centrifugal-flotation technique for separating nematodes from soil. Plant Disease Reporter, 48, 692.

Kellam, M.K. and Schenck, N.C. (1980), Interactions between a vesicular-arbuscular mycorrhizal fungi and root-knot nematode on soybean. Phytopathology, 70, 293-296.

Kormanic, P.P. and Mcgraw, A.C. (1984), Quantification of vesicular-arbuscular mycorrhiza in plant roots. In: Methods and Principles of Mycorrhizal Research, ed. N.C. Schenck, A.P.S. Press, St. Paul. pp. 37-45.

Kotcon, J.B., Bird, G.W., Rose, L.M. and Dimoff, K. (1985), Influence of Glomus fasciculatum and Meloidogyne hapla on Allium cepa in organic soils. Journal of Nematology, 17, 55-60.

Lordello, L.G.E. (1984), Nematóides das plantas cultivadas. Nobel, São Paulo.

Maia, L.C., Silveira, N.S.S. and Cavalcante, U.M.T. (2006), Interaction between arbuscular mycorrhizal fungi and root pathogens. In: Handbook of microbial biofertilizers. ed. M.K. Rai. pp. 325-351.

Miller, L.E. (1994), Correlations: description or inference? Journal of Agricultural Education, 35, 57.

Pandey, R., Gupta, M.L., Singh, H.B. and Krumar, S. (1999), The influence of vesicular-arbuscular mycorrhizal fungi alone or in combination with Meloidogyne incognita on Hyoscyamus niger L. Bioresource Technology, 69, 275-278.

Pinochet, J., Calvet, C., Camprubí, A. and Fernández, C. (1996), Interaction between migratory endoparasitic nematodes and arbuscular mycorrhizal fungi in perennial crops: a review. Plant and Soil, 185, 183-190.

Siddiqui, Z.A. and Mahmood, I. (1998), Effect of a plant growth promoting bacterium, an AM fungus and soil types on the morphometrics and reproduction of Meloidogyne javanica on tomato. Applied Soil Ecology, 8, 77-84.

Siddiqui, Z.A. and Mahmood, I. (1995), Role of plant symbionts in nematode management: a review. Bioresource Technology, 54, 217-226.

Sikora, R.A. and Sitaramaiah, K. (1980), Antagonistic interactions between the endotrophic mycorrhizal fungus Glomus mosseae and Rotylenchulus reniformis on cotton. Nematropica, 10, 72-73.

Smith, G.S., Hussey, R.S. and Roncadori, R. W. (1986), Penetration and postinfection development of Meloidogyne incognita on cotton as affected by Glomus intraradices and phosphorus. Journal of Nematology, 18, 429-435.

Smith, G.S. and Read, D.J. (1997), Mycorrhizal Symbiosis. Academic Press, London.

Society of Nematologists Crop Loss Assessment Committee (1987), Bibliography of estimated crop losses in the United States due to plant-parasitic nematodes. Annual Applied Nematology, 1, 6-12.

Strobel, N.E.; Hussey, R.S. and Roncadori, R.W. (1982), Interactions of vesicular-arbuscular mycorrhizal fungi, Meloidogyne incognita and soil fertility on peach. Phytopathology, 72, 690-694.

Suresh, C.K., Bagyaraj, D.J. and Reddy, D.D.R. (1985), Effect of vesicular-arbuscular mycorrhiza on survival, penetration and development of root-knot nematode in tomato. Plant and Soil, 87, 305-308.

Talavera, M., Itou, K. and Mizukubo, T. (2001), Reduction of nematode damage by root colonization with arbuscular mycorrhiza (Glomus spp.) in tomatoMeloidogyne incognita (Tylenchida: Meloidogynidae) and carrot-Pratylenchus penetrans (Tylenchida: Pratylenchidae) pathosystems. Applied Entomology and Zoology, 36, 387-392.

Umesh, K.C., Krishnappa, K. and Bagyaraj, D.J. (1988), Interaction of burrowing nematode, Radopholus similis (Cobb, 1983) Thorne 1949, and VA mycorrhiza, Glomus fasciculatum (Thaxt) Gerd and Trappe, in banana (Musa acuminata Colla). Indian Journal of Nematology, 18, 6-11.

Vaast, P.H., Caswell-Chen, E.P. and Zasoski, R.J. (1998), Influences of a root-lesion nematode, Pratylenchus coffeae, and two arbuscular mycorrhizal fungi, Acaulospora mellea and Glomus clarum on coffee (Coffea arabica L.). Biology and Fertility of Soils, 26, 130-135.
Received: June 02, 2008; Revised: October 09, 2008; Accepted: October 21, 2009. 
PÁGINA

EM

BRANCO 